\title{
Small Arms Proliferation and Armed Conflicts in Africa: The Case of Rwandan Conflict
}

\author{
Chuka Enuka \\ Nnamdi Azikiwe University, Awka, Nigeria
}

\section{INTRODUCTION}

The end of the cold war has been characterized by a wave of violent civil wars that have produced unprecedented humanitarian catastrophe and suffering. Although mostly intra-state, these conflicts have spread across borders and threatened international peace and security through mass refugees flow, proliferation of light arms, and the rise of local mercenary groups. One of the most affected areas is Africa, which has been the home of the world's most brutal and intractable conflicts for many decades. Beginning with the Liberian crisis which erupted in 1989, conflicts quickly spread to neighbouring Sierra-Leone in 1991. Subsequently, both Mali and Niger fought bitter wars with secessionist Tuareg rebels, while Senegal battled Casamance separatists (Kabia 2009). Guinea Bissau erupted into full scale war in 1997 following a power struggle between mutinous section of the army and the civilian government of president Nino Vieira. In September 2000, rebels from across the border of Liberia and Sierra-Leone invaded parts of Guinea, and by 2002, an army mutiny in Cote d'Ivoire commenced another round of conflicts in the continent.

The plausible causal explanation for these conflicts and their frequency has engaged the attention of scholars of different fields. While some analysts portray it as being generated by hatred and feelings of deep-seated animosity between and 
among ethnic groups, others have rejected that explanation as being insufficient (Verwimp 2006). Krain (1994) posited that ethnic factionalization is uncorrected with the onset of genocide or political mass murder as we found in Rwanda. The ethnic label put on many conflicts often mask the real reasons behind these conflicts. Economic analyses of conflict data for many countries has demonstrated that income, export, governance, population density and the presence of mineral wealth significantly influence the probability of civil war or genocide, and the inclusion of these variables weakens the effects of an ethnic hatred variable (Collier et al 2003, Soya 2002). Prevalence of conflicts has also been blamed on what has been called the 'weak state thesis' (Oche 2003, Ali 2006). According to this thesis, weak states display a low level of vertical legitimacy in that substantial portions of the society fail to display any loyalty to the rulers: the personification of the state demonstrated by the use of the apparatus of state for personal gain; and the absence of horizontal legitimacy or a feeling of community and a common conception of the state. Looking at it from the economic sphere, Elbadawi and Hegre (2003) think that 'economic shocks' fuel tension and greater concern for access to resources. Nnabudere (2000), Toyo (2000) have argued that globalization would increase national and local inequalities and that as long as distribution of resources remain as it is, there cannot but be an increase in inequality among and within states. This, according to Ali (2006) breeds conflicts.

While the root causes of armed conflicts in Africa may vary, it is unquestionable that small arms are a major challenge to security. The persistence and the increased number of wars in Africa are partially due to small arms proliferation. As Klare and Boutwell (2000) rightly put it, "Nowhere has the relation between the accessibility of light weapons and the outbreak and severity of conflict been more dramatically evident than in Africa" once competing groups have been armed with automatic weapons. Any minor dispute can escalate quickly into a major bloodbath. This factor of small arms proliferation is connected to the horrific scale of violence that engulfed Rwanda. The majority Hutu government and the minority Tutsi opposition both had been amply supplied with small arms and light weapons. Meijer (2005) found that few months before the genocide in Rwanda, Human Rights Watch presented evidence that the then government of Rwanda was buying 
weapons. The regime was distributing weapons among the population, using Rwanda's administration as part of the civilian self defense programme. One person per unit of ten households was armed (HRW 1994). Evidently, every nook and cranny of Rwandan society were saturated with small arms and light weapons. Guns, machine guns, grenades and large quantities of bullets were afloat. The role played by small arms in the Rwandan conflict has remained unexplored, yet important. An investigation of the role played by these weapons may help to prevent the indirect effects of small arms availability and misuse in Africa.

\section{SMALL ARMS AND CONFLICT IN AFRICA}

Since the end of the cold war, Africa has witnessed an outbreak of ethnic, religious and sectarian conflict characterized by routine massacre of civilians. Hundreds of conflicts erupted just between 1990 and 2000 alone (Boutwell and Klare 2000). These conflicts killed millions of people, devastated entire geographic regions, and left tens of millions refugees. Little of the destruction was inflicted by the tanks, artillery or aircraft usually associated with modern warfare. Rather most was carried out with pistols, machine guns and grenades. There are currently about fifteen African countries involved in war, or experiencing post-war conflict and tension. In West Africa the countries include Cote d'Ivoire, Guinea, Liberia, Sierra-Leone, Nigeria, and Togo. In East Africa, they are Eritrea, Ethiopia, Somalia, Sudan, and Uganda. In Central Africa, the countries include Burundi, Democratic Republic of Congo, and Rwanda. In North Africa, a war is being waged in Algeria. In Southern Africa, the countries experiencing a war are Angola, and Zimbabwe (Africa Sun News 2010). The persistence and the complication of wars in Africa are partially due to small arms proliferation. While the root causes of armed conflicts in Africa vary, it is unquestionable that small arms are a major challenge to security. The abundant supply of small arms, ammunition, light weapons and explosives circulating in African states since the end of the Cold War has made easy the escalation of tensions between groups facing disagreement. Massacres and massive human displacement become quick solutions when black market gun running is rampant. The relation between the accessibility of light weapons and the 
outbreak and severity of conflict has been more evident in Africa. In 1989, insurgent leader, Charles Taylor invaded Liberia with irregular soldiers primarily with AK-47 assault riffles. Within months, he had seized mineral and timber resources and used the profits to purchase additional light weapons. (Meijer 2005). Had he needed to equip his forces with heavier weapons such as artillery, armored cars and tanks, the weapons conventionally associated with a conquering army, Taylor would have faced crippling logistical obstacles. In comparison, a few boatloads of assault rifles, rocket-propelled grenades and machine guns were simple to transport and provided more than enough fire powder. In 1990, Taylor's ill-trained and undisciplined insurgents toppled the government of President Samuel Doe. Fighting continued for about seven years.

The current peace efforts in many Africa's conflict zones remain tenuous and highly dependent on what happens to the tens of thousands of weapons now in these countries. The disarmament programme in Liberia destroyed some 20,000 small arms and light weapons and more than three million rounds of ammunition by 1999 (Boutwell and Klare 2000). In Sierra-Leone, the failure to ensure a complete surrender of weapons by the former rebels and halt the circulation of small arms has led to renewed outbreaks of fighting in the recent times. In a more horrific circle of violence that engulfed Rwanda, the roles of small arms availability and proliferation was conspicuously evident. The majority Hutu government and the minority Tutsi opposition had been amply supplied with small arms and light weapons (Ngang 2007). The Hutu militia men armed with small arms and light weapons killed up to one million Tutsi and moderate Hutu in 1994.

The root causes of ethnic, religious and sectarian conflicts in Africa and around the world are of course more complex and varied, typically involving historical grievances, economic deprivation, demagogic leadership and an absence of democratic process, but the ready accessibility and low cost of small arms prolong combat, encourage a violent rather than a peaceful resolution of differences, and generate greater insecurity throughout society, which in turn leads to a spiraling demand for, and use of, such weapons. Once competing groups have been armed with weapons, any minor dispute can escalate quickly into a major bloodbath. The availability of weapons have made it difficult for the international community to 
bring the warring parties to the dialogue table in places like Sudan and Congo, even when a cease-fire is signed (Boutwell and Klare 2000).

What complicates the problems of small arms and the havocs it unleashes on Africa's peace and security is that it places weapons in the hands of untrained and undisciplined users. Only a few of these untrained fighters know something about the Geneva Conventions on human rights, and therefore, either specifically target civilians or fire indiscriminately into crowds, killing and wounding scores of noncombatants, women, children and international aid workers. Even after formal conflicts are over, the young ex-combatants who have known little else besides war usually have a high tendency of resorting to their weapons as a means of making a living through acts of street crime and organized operation.

Although proliferation of small arms generates money for those who manufacture them, African people pay a heavy price due to lack of accountability or international regulations to address the abuses those products cause. According to the Global Facilitation Network Security Sector Reform, nations such as France, Russia, UK, China and USA, the five permanent members of the United Nations Security Council, together account for 88 percent of the world's conventional arms exports (Bahati 2009). These exports contribute to gross abuses of human rights in Africa and elsewhere. Some of these are legal weapons sales to irresponsible governments who use them to oppress the people. Other supplies are made available to rebel groups by some countries in an effort to overthrow dictatorial regimes which in many cases become worse or as bad as the ousted regime. The United Nations General Assembly resolution subscribes to the idea that the absence of standards in arms sales is one of the contributory factors to conflict, the displacement of people and crimes. It undermines peace, reconciliation, safety and sustainable economic development (Bahati 2009).

Among nations that are culpable is the United States. The U.S. military policies in Africa have promoted dictatorship rather than democracy. The presence of U.S.-made weapons on the African continent has hurt the African people more than it has helped. The U.S legally transferred weapons contribute to feeding the illegal arms market which in turn, exacerbates conflict situations in Africa. It was 
U.S.-made weapons that supported the rebel groups RENAMO in Mozambique, UNITA in Angola, RPF in Rwanda and CNDP in the Democratic Republic of the Congo (DRC). In the UN experts' report on the crisis in the DRC, S/2008/773, paragraph 28 connects the origin of military uniforms shipment destined to the rebel group CNDP to the United States in these terms:

In October 2008, Rwandan security services seized a shipment of uniforms destined for CNDP at Kanombe airport in Kigali. ... The shipment reportedly originated in Boston, Massachusetts, United States (Bahati 2009).

Manufacturers of weapons know best the link between politics and weapons markets and are therefore often linked to the political instabilities in Africa to take advantage of the weapons business it creates. In her remarks to the Congress, McKinney, a former congresswoman stated that:

What we do know is that the U.S. Special Forces and U.S funded private military companies have been arming and training Rwandan and Ugandan troops to deadly effect. I think it is appalling that the U.S. taxpayer should be directly assisting the military efforts of Rwanda and Uganda, the aggressors in this tragic conflict and who are confirmed by Amnesty International and Human Rights Watch as the authors of terrible atrocities against Congolese civilians. Our efforts in Africa have amounted to nothing more than bankrolling belligerent and mass murder. (Bahati 2009).

\section{THE RWANDAN CONFLICT}

The Rwandan conflict, which claimed the lives of about one million Tutsis, was linked to the history and political beginning of the country. Right from after achieving independence, Rwanda has been deeply divided, with a very low pace of integration. The seed of hatred and discord between the Hutu and Tutsi ethnic groups, that later opened into a horrific genocidal killing, was sown from the years of colonial administration. Ethnographers and historians claim that the Hutus and the Tutsis are essentially the same people and cannot be really considered as 
ethnically different (Ngang 2007). The consciousness of deep divide and difference began with the arrival of the colonial powers, first Germany and later the Belgians in 1916. In dealing with the natives, the colonialists saw the lighter-skinned Tutsis as closer to the Europeans and considered the shorter and darker Hutus as Bantus (Ngang 2007). Attracted by the Tutsis' high stature, facial characteristics and leading position in the society, the colonizers concluded that the Tutsi are Hamitics, and are therefore genetically predestined to rule (Verwimp 2006). The Hutus on the other hand, being regarded as Bantu, a black race, are predestined to be ruled. As Ngang (2007) observed, this conception had damaging consequences for the development of the country and led to decades of preferential treatment of Tutsis in education, economic opportunities and power. The supported of the Tutsi monarchy contributed to that. But as years went by, the Tutsi's call and agitation for political independence of Rwanda from colonial stranglehold angered the Belgians, who then dramatically shifted their support to the Hutus, and supported their opposition to the Tutsi ascendancy. This led to the first massacre of the Tutsis, causing many to flee to Uganda. With the attainment of political independence in 1962, the newly privileged Hutus filled the space of the erstwhile colonizers. As the Hutu dominance continued, the ethnic separation and anti-Tutsi attitude worsened the economic situation in the 1970s and 1980s. The drop in coffee sales, the backbone of the Rwandan economy, from 14 billion Rwandan Francs to 5 billion between 1986 and 1987 alone, amid rising foreign deficit and corruption, aggravated the situation (Ngang 2007).

In October 1990, a group Tutsi who had been exiled to Uganda attacked Rwanda from Uganda. This attack ignited extremism among Hutu leaders. A civil war ensued, in which thousands of lives were lost. In order to end the crisis in Rwanda, a peace agreement was reached in Arusha, Tanzania. When in April 6, 1994, President Habyarimana came back from the Arusha meeting, his plane was shot down by two missiles over Kigali airport. With the shooting down of Habyarimana's plane, Rwanda entered its darkest period. Within hours, members of the Hutu-dominated government, presidential guards, police, and military started rounding up and executing opposition politicians. The army set up roadblocks at 50 to 100 meter intervals throughout Kigali. The airport was surrounded and sealed. 
Telephone lines were cut. Military intelligence distributed lists of the government's political opponents to death squads. "Every journalist, every lawyer, every professor, every teacher, every civil servant, every priest, every doctor, every clerk, every student, every civil rights activists was hunted down in a house-to-house operation (Melvern 2000). Anyone whose identity card showed a Tutsi affiliation was executed. The actors in the conflict were the Hutu government, Hutu youth militia, Interahamwe that supported it, and the Hutu populace in general. On the opposing side were the minority Tutsi militia group, the Rwandan Patriotic Front (RPF) and Tutsi populace. On the $9^{\text {th }}$ of April, the Interrahamwe militia, led by presidential guards, hacked to death 500 men, women and children who had taken shelter in the Catholic mission in Kigali (Holzgrefe 2003). In another incident, the Interahamwe shot 120 men who had taken refuge in St. Famille Church in Kigali. Soldiers killed any wounded Tutsi who made it to hospital. In Taba, the Interahamwe killed all male Tutsis, forced the women to dig graves to bury the men, and then threw the children in the graves. Holzgrefe captured the account of a survivor who said "I will never forget the sight of my son pleading with me not to bury him alive. He kept trying to come out and was beaten back. And we had to keep covering the pit with earth until there was no movement left. Massacres such as these became a commonplace throughout Rwanda. An estimated 43, 000 Tutsis were killed in Karama Gikongoro, a further 100, 000 massacred in Butare. Over 16,000 people were killed around Cyangugu; 4,000 in Kibeho; 5,500 in Cyahinda; 2,500 in Kibungo (Forges 1999). It was observed that one bloated and mutilated body plunged over the Rusomo Falls on Kagera River every minute (Holzgrefe 2003). From all indications it became obvious that a terrible genocidal madness has taken over Rwanda. In three months, as many as one million Tutsis were shot, burned, starved, tortured, stabbed or hacked to death (Melvern 2000).

\section{SMALL ARMS AND THE RWANDAN WAR}

Small arms and light weapons are not a side issue of the Rwandan genocide. They are a central feature of it (Meijer 2005). Reports had it that assault rifles, mortars and grenades were freely distributed throughout 2003 (Ngang 2007). Militia 
leaders received AK-47 assault rifles. Before the genocide started, 85 tons of ammunition had been handed out to the population and by the end of the year, the country was bursting full of guns. Their distribution was so open that at a press conference, a Bishop from Rwanda had to ask the government officials why they were arming civilians (Ngang 2007). In 1994, three months before the Rwandan genocide, Human Rights Watch presented evidence that the government was buying weapons that would be paid for partly in cash and partly with the future harvest of the Mulindi tea plantation (Human Rights Watch, 1994). The report states that the regime was distributing weapons among the population, thereby using the Rwandan administrative organization as part of a civilian self-defence programme. For instance in August 1991, Colonel Nsabimana, chief of staff of the Rwandan army, proposed to provide a gun for every administrative unit of ten households, "at least one person per Nyumba Kumi should be armed " (Verwimp 2006). Human Rights Watch documented how, in 1992-93, the head of the communal authority ordered quantities of arms and ammunition that far exceeded the needs of their local police forces (Verwimp 2006). They ordered guns, machine guns, grenades and large quantities of ammunition. The report also documents the purchase of many arms by the rebels, the Rwandan Patriotic Front (RPF). According to Verwimp (2006), boxes of small arms were found entering into Rwanda from Belgium. Wealthy businessmen as well as directors of state-owned companies used their resources to import, transport and distribute firearms as well as traditional weapons. The spread of these weapons was to both the rural and urban areas. Instructions were given on how many recruits should be trained, and what kind of weapons they should receive and how recruits should be trained to use them. To make up for the short supply of firearms, it was instructed that the civilian population should use machetes, spears, swords, bows and arrows. The military authorities at the national as well as the local levels prepared themselves to fight an enemy not at the war front, but dispersed among the population. Firearms were handed out to communal councilors, soldiers, army reservists and trained militia (Verwimp 2006). This policy was clearly meant to militarize the rural areas and draw the rural population into the conflict, however far they lived from the frontline. Ordinary farmers were told to participate in the self-defence programme with their own farming tools. 
The United Nations Security Council Resolution 918 imposed an arms embargo on Rwanda on May 17the, 1994, almost a month and a half after the genocide started. This implies that apart from arms that came in illegally, the weapons used during the genocide were acquired to a great extent before it actually started (Ngang 2007). Apart from France, other major arms suppliers to the Rwandan Armed Forces before the embargo included China, Egypt, Greece, Poland and South Africa. Uganda is considered to have strongly been the source of arms to the RPF side. Not only state actors were involved in weapons supplies but also private enterprises. The French company, DYL signed a multi-million dollar contract to deliver arms to Rwanda. Ngang (2007) observed that French companies were undisputed providers of arms to Rwanda. Not only did they carry out direct transfers to the country, they also helped in facilitating weapons deliveries by other countries. Even after the imposition of embargo on arms supplies to Rwanda, many European countries like France were found supplying to Rwanda either to the Hutu side or the Tutsi. Human Right Watch has the record of shipments of small arms into Rwanda through Goma, in Zaire. Zaire did not only help to facilitate deliveries by French through Goma, but also was actively involved in supplying small arms and light weapons to the Hutu group during the genocide.

Asit has been said, small arms were not a side issue in the Rwandan war, they were a central feature of it. Small arms were used not only for direct killing, but also to intimidate and mobilize the population into killing. In Bembe, Betenyo and Gayenzi, the Interahamwe militia leaders fired in the air arousing fear among the population. Firearms were thus used as a means of coercion, to make people do what they were not willing to do. In Gayezi, an Interahamwe leader was said to have fired in the air commanding the Hutus to start killing the Tutsis (Verwimp 2006). In addition to using guns to coerce Hutus to take action against the Tutsis, they were also used to perpetuate gender violence. Ngang (2007) recorded that Tutsi women were raped at gunpoint, many of whom became pregnant and others infected with HIV/AIDS. It is however, difficult to say with precision the number that died as a result of the use of firearms in the Rwandan conflict, but popular records have it that up to one million lives were claimed. 


\section{CONCLUSION}

It is an incontestable fact that the proliferation of arms impacts negatively on the conflict situation in Africa and elsewhere. The Rwandan genocidal war is a case in point. Having realized the chaos and devastation wrought by the influx of small arms and light weapons, political leaders of various countries are pushing for control on the spread and sale of arms. Representatives of 21 countries met in Oslo in 1998 and agreed to work together to curb the proliferation of light weapons. The United Nations has also called on member states to tighten their munitions export regulations and to cooperate in efforts to suppress illicit trade in small arms. In Africa, there has been the Bamako Declaration on illicit proliferation, circulation and trafficking of small arms, the SADC Protocol on firearms, ammunition and other related materials. However, a substantial weakness that can be found in almost all these actions is that their major focus is on illicit arms proliferation, and not on the arms trade itself. As long as laws and policies governing the arms trade per se are not reviewed, the difficulties to effectively tackle small arms and light weapons proliferation will continue to exist. Illicit weapons have legal origin. It is therefore of the utmost importance to look at better ways of controlling the legal trade in firearms to make sure that weapons that are traded legally are not diverted into the illegal market. It is also important to target the problems of arms proliferation by looking at the root causes of what in the first place raises their demand. Ethnic imbalance created by colonialism, and deepened by bad governance, should be addressed. As long as politics in Africa remains ethnicallt-based, the African continent is less likely to see an end of intra-state wars, as was the case in Rwanda.

\section{References and Notes}

AfricanSunNews, (2010), “About Wars and Post-War Conflicts"

http://www.africasunnews.com/warshtml.

Ali W (2006) "The Impact of Globalization on Conflicts in Africa" in Best G (ed), Introduction to Peace and Conflict Studies in West Africa. Abuja: Spectrum

Bahati J (2009), Impact of Small Arms Proliferation on Africa. Washington: AFJN

Boutwell, J and Klare, M (2000), A Scourge of Small Arms. Cambridge: American 
Academy of Arts and Social Sciences

Collier, P et al (2003), Breaking the Conflict Trap: Civil War and Development Policy. Washington DC: World Bank

Elbadawi, I and Hegre, H (2003), "Globalization, Economic Shocks and Armed Conflicts" Paper presented at the ECPR Conference Marburg, Germany, Sept. 18-21

Forges, A (1999) Leave No One to Tell the Story: Genocide in Rwanda. New York: Human Right Watch.

Hintjens, M (1999) "Explaining the 1994 Genocide in Rwanda" Journal of Modern African Studies, Vol 37, No2, p.273.

Holzgrefe, J (2003) “The Humanitarian Intervention Debate” in Holzgrefe, J and Keohane R, (eds) Humanitarian Intervention: Ethical, Legal and Political Dilemmas. UK: Cambridge

Human Rights Watch (1994) Arming Rwanda: The Arms Trade and Human Rights Abuses in the Rwandan War. New York: HRW.

Kabia, J (2009) Humanitarian Intervention and Conflict Resolution in West Africa: From ECOMOG to ECOMIL. England: Ashgate

Kaplan, R (1994) “The Coming Anarchy” Atlantic Monthly, February, pp.44-76

Krain, M (1997) "State-Sponsored Mass Murder: The Onset and Severity of Genocides and Politicides" Journal of Conflict Resolution 41(3): 331-360

Meijer, C (2005) The Use and Perception of Weapons Before and After Conflict: Evidence from Rwanda. Small Arms Survey. Working Paper 2.

Melvern, L (1997) “Genocide Behind the Blue Line” Security Dialogue, Vol 28, No3.

Melvern, L (2000) A People Betrayed: The Role of the West in Rwanda's Genocide. London: Zed Books

Nabudere, D (2000), Globalization and the African Post Colonial State. Harare: AAPS Books

Ngang, C (2007) Small Arms and Light Weapons: The Role of Small Arms and Light Weapons in Conflict and Security in Sub-Saharan Africa. Austria: EUCPS

Soya, I (2002) "Paradise is a Bazaar: Greed, Creed and Governance in Civil War, 1989-1999” Journal of Peace Research, 39 (4): 395-416

Verwimp, P (2006) "Machetes and Firearms: The Organization of Massacres in Rwanda" Journal of Peace Research Vol 43, No 1, pp.5-22 


\title{
Summary
}

\section{Small Arms Proliferation and Armed Conflicts in Africa: The Case of Rwandan Conflict}

\author{
Chuka Enuka \\ Nnamdi Azikiwe University, Awka, Nigeria
}

This paper studies of the use of small arms in the Rwandan civil wars that resulted to a spate of genocidal killings that shocked the moral conscience of mankind. Notwithstanding the importance of small arms during conflicts, analytic studies of their roles and use during intensive episodes of violence are nearly absent. Conflict studies often stress the curse of mineral wealth, but they neglect the fact that one does not kill a human being with a gallon of oil or a sparkling diamond. Without weapons, conflicts within and between countries wouldl not reach the toll on human lives as we have seen in the recent bloody conflicts in Sierra-Leone, the Democratic Republic of Congo, Sudan and Rwanda. In view of this, the paper intends to contribute to the understanding of the importance of the use and role of small weapons in Rwanda, and more generally, the importance of small and light weapons in other kinds of conflict. The main finding of this study inter alia is that though ethnic imbalance, created by colonialism and deepened by bad governance, necessitated a conflict situation in Rwanda, but the proliferation of small arms within Rwandan society worsened the conflict. The paper posits that mere legislation is an insufficient answer to the problems of small arms proliferation. It suggests that a look at the root causes of what in the first place raises the demand of small arms is imperative.

KEY WORDS: Armed Conflict; Small Arms; Light Weapons; Interahamwe Militia; Rwandan War; Genocidal Killing; Hutus and Tutsis. 